\title{
The morphology of diaphragmatic defects in hepatic hydrothorax: Thoracoscopic finding
}

\author{
Pei-Ming Huang, MD, ${ }^{a}$ Yih-Leong Chang, MD, ${ }^{b}$ Ching-Yao Yang, MD, a and Yung-Chie Lee, MD, PhD
}

Background: Until now, the pathophysiology of hepatic hydrothorax has been moot. We discuss (on the basis of gross videothoracoscopy findings in 11 cases and the literature) the pathogenesis and clinical presentation of this complex condition.

Methods: We prospectively studied 11 patients (age, 31-73 years; 6 men and 5 women) with refractory hepatic hydrothorax (Child-Pugh class B-C) who underwent thoracoscopic repair of diaphragmatic defects. The diaphragmatic defects were examined intraoperatively.

Results: The diaphragmatic defects stemming from hepatic hydrothorax were classified into 4 morphologic types: type I, no obvious defect (1 patient); type II, blebs lying on the diaphragm (4 patients); type III, broken defects (fenestrations) in the diaphragm (8 patients); and type IV, multiple gaps in the diaphragm (1 patient). The type of diaphragmatic defect did not correlate with the volume occupied by the pleural effusion in the preoperative chest radiograms.

Conclusions: The finding of this study allowed hepatic hydrothorax pathophysiology to be directly visualized, and further studies concerning the treatment of hepatic hydrothorax might be based on these mechanisms.

From the Division of Thoracic Surgery ${ }^{\mathrm{a}}$ and the Department of Surgery and Pathology, ${ }^{\mathrm{b}}$ National Taiwan University Hospital and National Taiwan University College of Medicine, Taipei, Taiwan.

Received for publication April 3, 2004; revisions received July 16, 2004; accepted for publication Aug 20, 2004

Address for reprints: Yung-Chie Lee, MD, $\mathrm{PhD}$, Division of Thoracic Surgery, Department of Surgery, National Taiwan University Hospital, No. 7, Chung-Shan S. Rd, Taipei 100, Taiwan (E-mail: wuj@ha.mc. ntu.edu.tw)

J Thorac Cardiovasc Surg 2005;130:141-5

$0022-5223 / \$ 30.00$

Copyright (C) 2005 by The American Association for Thoracic Surgery

doi:10.1016/j.jtcvs.2004.08.051
$\mathrm{H}$ epatic hydrothorax $(\mathrm{HH})$ has been observed in approximately $1 \%$ to $10 \%$ of cirrhotic patients. ${ }^{1,2}$ This condition is defined as the presence, in a cirrhotic patient, of massive pleural effusion in the absence of primary pulmonary or cardiac disease. $^{2}$ The real mechanism for $\mathrm{HH}$ is unclear, although many mechanisms have been reported. Most findings have been obtained from autopsy reports. ${ }^{3-6}$ There is accumulating evidence that diaphragmatic defects have a role in those cases of $\mathrm{HH}$ in which blebs or fenestrations allow peritoneopleural communication. ${ }^{4,7,8}$ To our knowledge, the relationship between diaphragmatic defects and $\mathrm{HH}$ has not been systematically studied in living patients. On the assumption that diaphragmatic defects might be involved in the pathogenesis of $\mathrm{HH}$, we studied the effects of thoracoscopic repair in a prospective trial involving patients with $\mathrm{HH}$ who were refractory to medical treatment, including thoracentesis, diuretics, and pleurodesis.

\section{Patients and Methods}

Between October 2002 and November 2003, 11 patients (age, 31-73 years; 6 men and 5 women) with Child-Pugh class B-C liver cirrhosis complicated by $\mathrm{HH}$ were prospectively studied at the National Taiwan University Hospital. Their preoperative clinical features and biochemical characteristics are summarized in Table 1. No patient with a past history of pulmonary or cardiogenic causes was included. Of all patients, none ever had successful management of their pleural effusions. The diagnosis of $\mathrm{HH}$ was confirmed on the basis of the presence of a history of cirrhosis, physical examination, biochemical profile, chest radiography, chest computed tomography, and radionuclide study. The pleural effusion volume was estimated on the basis of chest radiography. All patients provided written informed consent. Three of these patients had renal failure with regular hemodialysis. All 
TABLE 1. Clinical demographics of patients with hepatic hydrothorax

\begin{tabular}{|c|c|c|c|c|c|c|c|c|c|c|c|}
\hline $\begin{array}{c}\text { Case } \\
\text { no. }\end{array}$ & $\begin{array}{c}\text { Age } \\
\text { (y)/sex }\end{array}$ & Clinical presentation & $\begin{array}{l}\text { Radiologic } \\
\text { study }\end{array}$ & Ascites & $\begin{array}{c}\text { Albumin } \\
\text { (g/dL) }\end{array}$ & $\begin{array}{l}\text { T-Bil } \\
\text { (mg/ } \\
\text { dL) }\end{array}$ & $\begin{array}{c}\text { PIt } \\
(x \\
\left.10^{3}\right)\end{array}$ & $\begin{array}{c}\text { Prothrombin } \\
\text { time (s) }\end{array}$ & $\begin{array}{c}\text { Preoperative } \\
\text { period of } \mathrm{HH} \\
\text { (mo) }\end{array}$ & $\begin{array}{c}\text { No. of } \\
\text { preoperative } \\
\text { pleurodeses }\end{array}$ & $\begin{array}{c}\text { Operative } \\
\text { finding }\end{array}$ \\
\hline 1 & $66 / \mathrm{M}$ & $\begin{array}{l}\text { Alcoholic LC, child B, } \\
\text { chronic renal failure }\end{array}$ & $\begin{array}{l}\text { Rt PE: } 2 / 3 \\
\text { hemithorax }\end{array}$ & Present & 2.9 & 0.5 & 54 & 14.5 & 9 & 6 & $\begin{array}{l}\text { Type II, } \\
\text { III, }\end{array}$ \\
\hline 2 & $31 / \mathrm{M}$ & $\begin{array}{l}\text { Alcoholic LC, child C, } \\
\text { Septic shock, LLL } \\
\text { pneumonia, acute } \\
\text { renal failure }\end{array}$ & $\begin{array}{l}\text { Rt tension } \\
\text { hydrothorax }\end{array}$ & Present & 2.6 & 0.6 & 375 & 18.2 & 2 & 4 & Type III \\
\hline 3 & $61 / \mathrm{M}$ & HBV, HCV, child C LC & $\begin{array}{c}\text { Rt PE: } 2 / 3 \\
\text { hemithorax }\end{array}$ & Present & 2.8 & 2.3 & 44 & 18.8 & 6 & 5 & $\begin{array}{l}\text { Type II, } \\
\text { III, IV }\end{array}$ \\
\hline 4 & $56 / F$ & HBV, child C LC & $\begin{array}{c}\text { Rt PE: } 2 / 3 \\
\text { hemithorax }\end{array}$ & Absent & 3.7 & 3.9 & 78 & 19.4 & 1 & 3 & $\begin{array}{c}\text { Type II, } \\
\text { III }\end{array}$ \\
\hline 5 & $68 / \mathrm{M}$ & HCV, child C LC, HCV & $\begin{array}{l}\text { Rt tension } \\
\text { hydrothorax }\end{array}$ & Present & 2.7 & 8.2 & 41 & 22.8 & 4 & 6 & Type II \\
\hline 6 & $63 / \mathrm{F}$ & Child C LC, HCV & $\begin{array}{l}\text { Rt tension } \\
\text { hydrothorax }\end{array}$ & Present & 1.9 & 2.9 & 79 & 16.6 & 1 & 4 & Type III \\
\hline 7 & $73 / F$ & Child C LC, DM, UTI & $\begin{array}{c}\text { Rt PE: } 2 / 3 \\
\text { hemithorax }\end{array}$ & Absent & 4.2 & 3.3 & 48 & 16.7 & 2 & 6 & Type III \\
\hline 8 & $65 / F$ & Child C LC, HCV & $\begin{array}{l}\text { Rt PE: } 2 / 3 \\
\text { hemithorax }\end{array}$ & Present & 1.9 & 0.7 & 40 & 17.6 & 2 & 3 & Type III \\
\hline 9 & $69 / \mathrm{F}$ & Child C LC & $\begin{array}{c}\text { Rt PE: } 1 / 2 \\
\text { hemothorax }\end{array}$ & Present & 2.5 & 4.3 & 76 & 15.6 & 2 & 3 & Type III \\
\hline 10 & $46 / \mathrm{M}$ & $\begin{array}{l}\text { Child C LC, HCV, DM, } \\
\text { chronic renal failure }\end{array}$ & $\begin{array}{c}\text { Rt PE: } 1 / 2 \\
\text { hemithorax }\end{array}$ & Present & 3.4 & 0.6 & 183 & 13.5 & 2 & 2 & Type II \\
\hline 11 & $62 / \mathrm{M}$ & Child C LC & $\begin{array}{c}\text { Bilateral } \\
\text { PE: } 1 / 2 \\
\text { hemithorax }\end{array}$ & Present & 2.9 & 1.1 & 68 & 15.4 & 3 & 4 & Type III \\
\hline
\end{tabular}

$T$-Bil, Total bilirubin; Plt, platelets; $H H$, hepatic hydrothorax; $L C$, liver cirrhosis; $P E$, pleural effusion; $R$, right; $L L L$, left lower lobe; $H B V$, hepatitis $B$ virus; $H C V$, hepatitis $C$ virus; DM, diabetes mellitus; UTI, urinary tract infection.

patients had intractable shortness of breath and were transferred for surgical intervention after medical treatment failure, including minocyclin or picibanil pleurodesis, and 2 of these patients had limited activity with bed rest only. The patients were scheduled for surgical intervention as soon as possible to achieve early control of respiratory failure. One patient was hospitalized initially at our institution with septic shock caused by left-sided pneumonia. We performed thoracoscopic repair of diaphragmatic defects because impending respiratory failure and mortality would predicate in bilateral pulmonary problems (massive pleural effusion in the right side and lobar pneumonia in the left side).

Needle thoracentesis was carried out early to differentiate transudates from exudates in the course of the illness. If their prothrombin time and partial thrombin time were prolonged, patients routinely received platelet and fresh frozen plasma infusion to correct thrombocytopenia stemming from splenomegaly and bleeding tendency. After achievement of general anesthesia, the videothoracoscopic instruments were inserted through 3 trocar sites: a 10-mm trocar through the ninth intercostal space in the midaxillary line for insertion of the optical unit and two $1.5-\mathrm{cm}$ wounds (one at an anterior site in the fifth intercostal space and the other at a posterior site in the fourth intercostal space). A total of $200 \mathrm{~mL}$ of saline solution with $2 \mathrm{~mL}$ of methylene blue was routinely injected into the peritoneal cavity through a $2-\mathrm{cm}$ ab- dominal wound to detect the diaphragmatic defects. We repaired the defects with 4-0 Prolene sutures and performed minocyclin pleurodesis postoperatively.

\section{Results}

The operative findings of all the patients are summarized in Table 1. The pleural fluid is characteristically a transudate and is usually similar to that found in the peritoneal cavity. The mean serum albumin concentration for all patients was $2.9 \pm 0.7 \mathrm{mg} / \mathrm{dL}$. The values for serum bilirubin (mean value, $2.6 \pm 2.3 \mathrm{mg} / \mathrm{dL}$ ) and prothrombin time (mean value, $17.2 \pm 2.6$ seconds) were significantly higher in these patients. In 4 of the patients with $\mathrm{HH}$, peritoneal and pleural fluids also were available for analysis during an episode of spontaneous bacterial peritonitis. The preoperative chemical pleurodesis with minocyclin only caused mild adhesion at the posterior surface of the pulmonary parenchyma in the condition of massive pleural effusion.

All defects were located on the tendinous area of the diaphragm, and one was near the orifice of the inferior vena cava. We classified the diaphragmatic defects associated with the development of $\mathrm{HH}$ into 4 morphologic types 
TABLE 2. The gross appearance of the diaphragmatic defects of hepatic hydrothorax

\begin{tabular}{|c|c|c|c|c|}
\hline Author & $\begin{array}{l}\text { Type I: } \\
\text { No } \\
\text { obvious } \\
\text { defect }\end{array}$ & $\begin{array}{c}\text { Type II: } \\
\text { Blebs } \\
\text { lying on } \\
\text { diaphragm }\end{array}$ & $\begin{array}{c}\text { Type III: } \\
\text { Broken } \\
\text { defects } \\
\text { (fenestrations) } \\
\text { of the } \\
\text { diaphragm }\end{array}$ & $\begin{array}{c}\text { Type IV: } \\
\text { Multiple } \\
\text { gaps of } \\
\text { the } \\
\text { diaphragm }\end{array}$ \\
\hline $\begin{array}{l}\text { Chen } \\
\text { and } \\
\text { coworkers, } \\
\text { review } \\
\text { article }\end{array}$ & & 6 & 6 & \\
\hline $\begin{array}{l}\text { Kakizaki } \\
\text { and } \\
\text { coworkers, }{ }^{7} \\
\text { review } \\
\text { article }\end{array}$ & 7 & 1 & 12 & \\
\hline $\begin{array}{l}\text { Current } \\
\text { report, } \\
\text { single } \\
\text { institution }\end{array}$ & 1 & 4 & 8 & 1 \\
\hline
\end{tabular}

(Table 2$)^{6,7}$ : type I, no obvious defect; type II, blebs lying on the diaphragm (Figure 1); type III, broken defects (fenestrations) in the diaphragm (Figure 2); and type IV, multiple gaps in the diaphragm (Figure 3). The blebs were possibly 1 to $2 \mathrm{~cm}$ in diameter. The type III broken defects usually appeared in a streak-like arrangement. They were round to ovoid, showed diffuse infiltrative margins, and were composed of fenestrations and broken blebs. The lymphatic tracts could be delineated in type III defects by means of injection of methylene blue through the abdominal wound. Leakage of many drops of fluid (oozing) from type IV diaphragmatic defects was in some cases seen 10 minutes after suction drainage of the pleural effusion (Figure 3).

A diaphragmatic defect could not be determined accurately in one patient. Type II (4 patients) and III (8 patients) defects were more frequently observed. No relationship was found between the type of diaphragmatic defect and the volume of occupied pleural effusion. These 4 types of diaphragmatic defects could occur simultaneously.

\section{Discussion}

The implications of studies on $\mathrm{HH}$ pathogenesis carried out during the last 50 years remain unclear. Several explanations for $\mathrm{HH}$ development have been proposed, including hypoalbuminemia, azygous vein hypertension, leakage from the thoracic duct, transdiaphragmatic lymphatic migration, and pressure gradient-directed flow through diaphragmatic defects. ${ }^{8}$ However, in one study the transdiaphragmatic flow of ascitic fluid through a diaphragmatic defect was demonstrated by using the intraperitoneal injection of air, dye, or
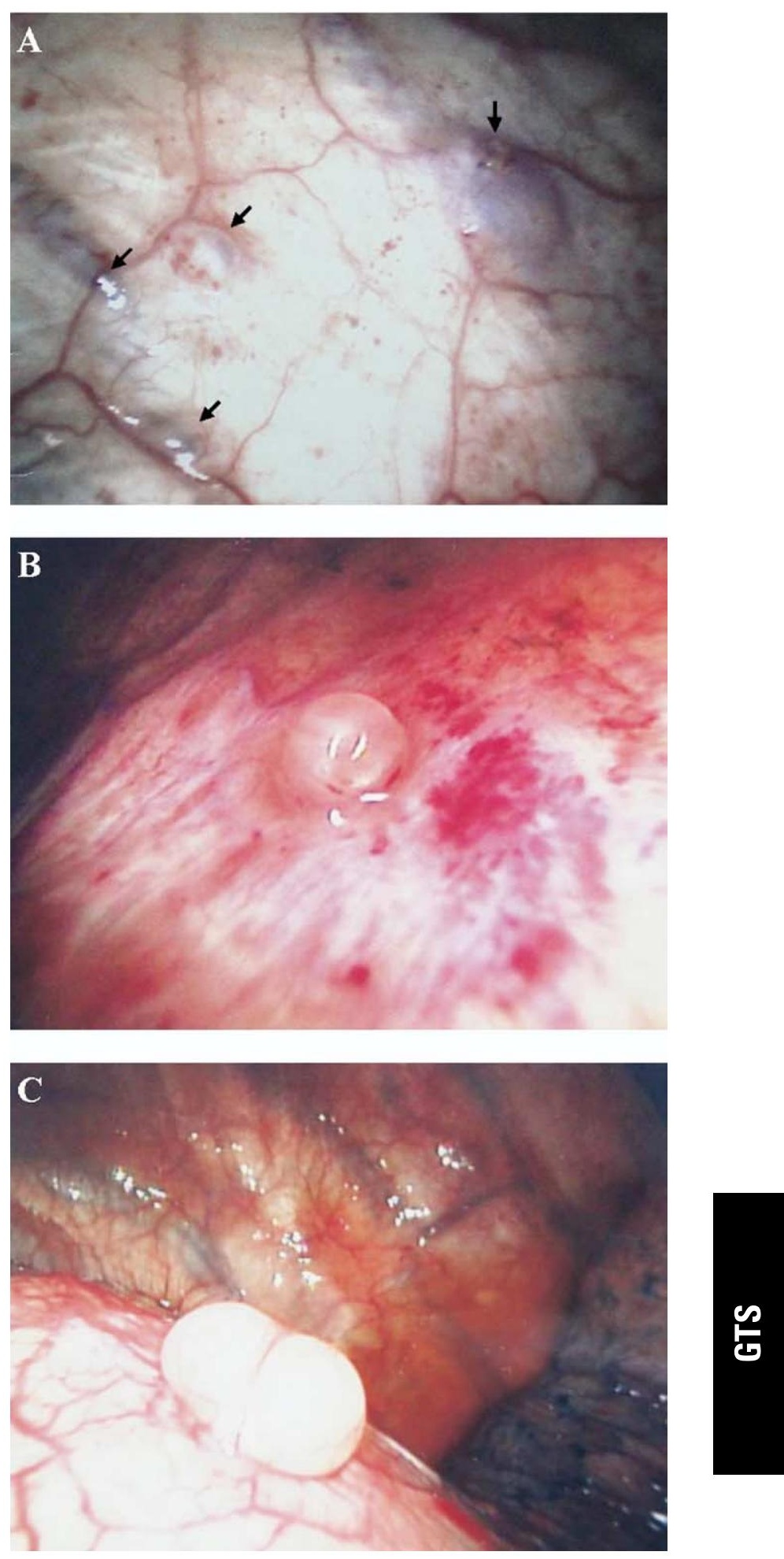

Figure 1. Type II diaphragmatic defect in HH (A-C). The blebs possibly change from 1 to $2 \mathrm{~cm}$ in diameter. 

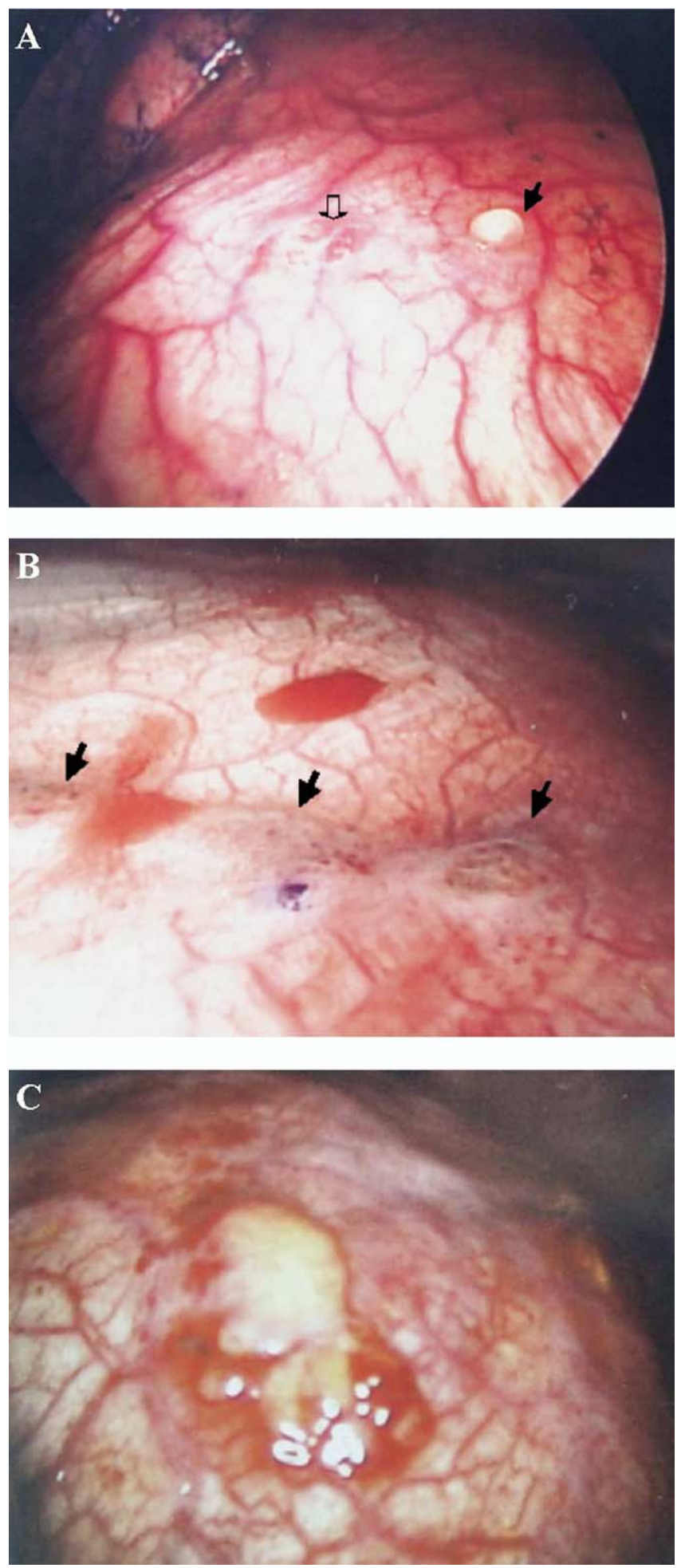

Figure 2. Type III diaphragmatic defect in HH. A, A different type of diaphragmatic defect could occur simultaneously. B, Some pigmented rough surfaces represent the lymphatic tract on the diaphragm after methylene blue being injected into the peritoneal cavity. C, Numerous bead-like rough surfaces can be seen on the diaphragm.

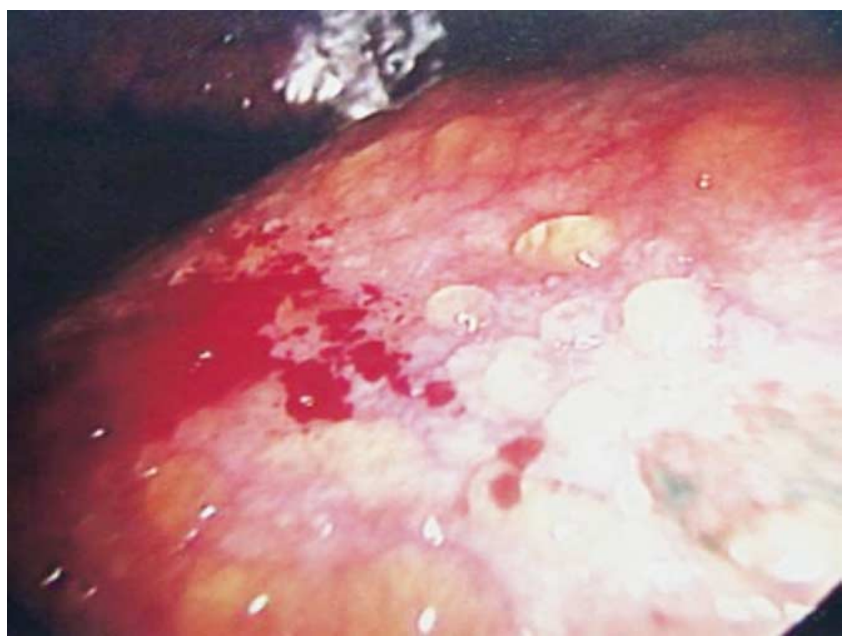

Figure 3. Leakage of many drops of fluid (oozing) from a type IV diaphragmatic defect in HH was noted in some cases.

a radionuclide. ${ }^{9,10}$ Because of the small numbers of patients studied, several key questions remain. Moreover, hepatitis is a serious health problem in Taiwan. Liver cirrhosis and hepatoma, which are both closely correlated with hepatitis B and $\mathrm{C}$, are among the 10 leading causes of death in Taiwan. The prevalence of hepatitis $\mathrm{B}$ surface antigen and antihepatitis $C$ virus in Taiwan were $12.6 \%$ and $41.6 \%$, respectively. ${ }^{11}$ Review of the literature revealed that no method to date has been proved directly, and the present study provides direct visualization of the gross appearance of diaphragmatic defects.

This report raises the question of whether repair of these diaphragmatic defects decreases the risk of $\mathrm{HH}$. It poses a serious management challenge because these patients also have multiple organ dysfunctions. Various modalities have been used in the past, with varying degrees of success. Video-assisted thoracoscopic repair of diaphragmatic defects was reported recently. ${ }^{12,13}$ The magnification afforded by the optical system allows for excellent localization of diaphragmatic defects.

The relationship of diaphragmatic defects to $\mathrm{HH}$ might be considered in decision making during operative treatment. In localized defects, such as type II (blebs) and III (fenestrations) defects, primary suturing is reasonable, but in type IV (diffuse oozing) defects, only primary repair or repeat pleurodesis might not benefit. Mesh, tissue glue, or flap might be considered for interruption of persistent leakage from these diaphragmatic defects. They need further evaluation to determine whether our findings could provide some pathophysiologic basis. As the diaphragmatic blebs progress and eventually rupture, type III defects might result. The source of diaphragmatic defects could be detected with intraperitoneal methylene blue injection, which guided 
the definitive surgical treatment, in cases involving type III defects. Macroscopically, a type III defect is characterized by using a unique combination of clusters of lymphatic tracts (Figure 2). This finding prompted us to investigate the possible role of pleural effusion leakage from these lymphatic tracts. Diaphragmatic defects might occur in a variety of sites but most commonly arise in the tendinous portion of the diaphragm. These defects are usually difficult to observe by using ultrasonography and magnetic resonance imaging in type II and IV defects. Our observation could explain that only the type III defect with large fenestrations could be detected by using these imaging methods. ${ }^{14}$

In another opinion spontaneous bacterial empyema can occur in $13 \%$ of cirrhotic patients who have $\mathrm{HH}$ both with and without ascites. ${ }^{15-17}$ The pathogenesis of spontaneous bacterial empyema remains unknown ${ }^{15}$ and might be explained by the communication between the diaphragmatic defects. Finally, the finding of this study allowed HH pathophysiology to be directly visualized. Further studies about the treatment of $\mathrm{HH}$ might be based on these mechanisms.

\section{References}

1. Johnston RF, Loo RV. Hepatic hydrothorax. Studies to determine the source of the fluid and report of thirteen cases. Ann Intern Med. 1964;61:385-401.

2. Morrow CS, Kantor M, Armen RN. Hepatic hydrothorax. Ann Intern Med. 1958;49:193-203.

3. Emerson PA, Davies JH. Hydrothorax complicating ascites. Lancet. $1955 ; 1: 487-8$.
4. Liberman FL, Peter RL. Cirrhotic hydrothorax. Further evidence that an acquired diaphragmatic defect is at fault. Arch Intern Med. 1970; 125:144-7.

5. Singer JA, Kaplan MM, Katz RL. Cirrhotic pleural effusion in the absence of ascites. Gastroenterology. 1977;73:575-7.

6. Chen A, Ho YS, Tu YC, Tang HS, Cheng TC. Diaphragmatic defect as a cause of massive hydrothorax in cirrhosis of liver. J Clin Gastroenterol. 1988;10:663-6.

7. Kakizaki S, Katakai K, Yoshinaga T, Higuchi T, Takayama H, Takagi $\mathrm{H}$, et al. Hepatic hydrothorax in the absence of ascites. Liver. 1998; 18:216-20.

8. Kirsch CM, Chui DW, Yenokida GG, Jensen WA, Bascom PB. Hepatic hydrothorax without ascites. Am J Med Sci. 1991;302:103-6.

9. Lieberman FL, Hidemura R, Peters RL, Reynolds TB. Pathogenesis and treatment of hydrothorax complicating cirrhosis with ascites. Ann Intern Med. 1966;64:341-51.

10. Rubinstein D, McInnes IE, Dudley FJ. Hepatic hydrothorax in the absence of clinical ascites: diagnosis and management. Gastroenterology. 1985;88:188-91.

11. Lu SN, Chen TM, Lee CM, Wang JH, Tung HD, Wu JC. Molecular epidemiological and clinical aspects of hepatitis $\mathrm{D}$ virus in a unique triple hepatitis viruses (B, C, D) endemic community in Taiwan. J Med Virol. 2003;70:74-80.

12. Mourous J, Perrin C, Venissac N, Blaive B, Richelme H. Management of pleural effusion of cirrhotic origin. Chest. 1996;109:1093-6.

13. Temes RT, Davis MS, Follis FM, Pett J, Wernly JA. Videothoracoscopic treatment of hepatic hydrothorax. Ann Thorac Surg. 1997;64: 1468-9.

14. Zenda T, Miyamoto S, Murata S, Mabuchi H. Detection of diaphragmatic defect as the cause of severe hepatic hydrothorax with magnetic resonance imaging. Am J Gastroenterol. 1998;93:2288-9.

15. Xiol X, Castellote J, Baliellas C, Ariza J, Gimenez Roca A, Guardiola $\mathrm{J}$, et al. Spontaneous bacterial empyema in cirrhotic patients: analysis of eleven cases. Hepatology. 1990;11:365-73.

16. Abba AA, Laajam MA, Zargar SA. Spontaneous neutrocytic hepatic hydrothorax without ascites. Respir Med. 1996;90:631-4.

17. Xiol X, Guardiola J. Hepatic hydrothorax. Curr Opin Pulm Med. 1998;4:239-42. 